\title{
Article \\ Preliminary Investigation on Degradation Behavior and Cytocompatibility of Ca-P-Sr Coated Pure Zinc
}

\author{
Mingfeng Ke ${ }^{1}$, Danhua Xie ${ }^{2}$, Qiangqiang Tang ${ }^{3}$ and Shenghui Su ${ }^{1, *}$ \\ 1 Department of Orthopedics, Ningde Municipal Hospital of Ningde Normal University, Ningde 352100, China; \\ kmf98@163.com \\ 2 Fujian Provincial Key Laboratory of Featured Materials in Biochemical Industry, College of Chemistry and \\ Materials, Ningde Normal University, Ningde 352100, China; danhuaxie@ndnu.edu.cn \\ 3 School of Materials Science and Engineering, South China University of Technology, \\ Guangzhou 510640, China; tozide2021@163.com \\ * Correspondence: sushenghui27@163.com
}

check for updates

Citation: Ke, M.; Xie, D.; Tang, Q.; Su, S. Preliminary Investigation on Degradation Behavior and Cytocompatibility of Ca-P-Sr Coated Pure Zinc. Coatings 2022, 12, 43. https: / / doi.org/10.3390/coatings 12010043

Academic Editor: Seunghan Oh

Received: 21 November 2021

Accepted: 15 December 2021

Published: 31 December 2021

Publisher's Note: MDPI stays neutral with regard to jurisdictional claims in published maps and institutional affiliations.

Copyright: (C) 2021 by the authors. Licensee MDPI, Basel, Switzerland. This article is an open access article distributed under the terms and conditions of the Creative Commons Attribution (CC BY) license (https:// creativecommons.org/licenses/by/ $4.0 /$ )

\begin{abstract}
Zinc and its alloys show a good application prospect as a new biodegradable material However, one of the drawbacks is that $\mathrm{Zn}$ and its alloys would induce the release of more $\mathrm{Zn}$ ions, which are reported to be cytotoxic to cells. In this study, a Ca-P-Sr bioactive coating was prepared on the surface of pure zinc by the hydrothermal method to address this issue. The morphology, thickness, and composition were characterized, and the effects of the coating on the degradation, cell viability, and ALP staining were investigated. The results demonstrated that the degradation rate of pure zinc was reduced, while the cytocompatibility was significantly improved after pure zinc was treated with Ca-P-Sr coating. It is considered that the Ca-P-Sr bioactive coating prepared by the hydrothermal method has promising application in the clinic.
\end{abstract}

Keywords: coating; zinc; degradation behavior; cytocompatibility

\section{Introduction}

In recent years, biodegradable zinc and its alloys have attracted a lot of attention from researchers [1,2]. The corrosion rate of pure magnesium is very rapid, $\sim 0.34-2.52 \mathrm{~mm} / \mathrm{a}$, and the complete degradation will be achieved within 120 days, which severely limits the application of magnesium-based alloys [3]. In contrast, the corrosion rate of pure iron is very slow, $\sim 0.008-0.52 \mathrm{~mm} / \mathrm{a}$ [4]; moreover, the corrosion products of iron-based alloy implants are relatively stable and cannot be quickly absorbed by the human body, which will cause problems similar to the inner membrane hyperplasia and in-tube restenosis caused by the implantation of permanent metal materials. Zinc, an essential trace element, is involved in and affects the activity of more than 300 enzymes in the body [5]. The body contains about $2.5 \mathrm{~g}$ of zinc, present in almost all human tissues, mainly in muscle, liver, and bones [2,6]. Zinc is also involved in processes including nucleic acid metabolism, signaling, apoptosis, and regulation of gene expression. The lack of zinc in the human body will cause physical dysplasia, decreased appetite, decreased immune function, and hinder the human body's absorption of vitamins [7]. More importantly, the corrosion potential of zinc $(-0.763 \mathrm{~V})$ is intermediate between magnesium " $(-2.37 \mathrm{~V})$ and iron $(-0.440 \mathrm{~V})$ " [8]. Bowen et al. [9]. found that the corrosion rate of pure zinc wires in adult rats was about 0.02 $\mathrm{mm}$ /year 1.5 months after implantation, which increased to $\approx 0.05 \mathrm{~mm} /$ year after 6 months. Therefore, the ideal benchmark value for the degradation rate of zinc is $0.02 \mathrm{~mm} /$ year [10]. Given this, zinc and its alloys have a more appropriate corrosion rate in the environment in the human body, which meets the degradation rate requirements of most in vivo implants. Moreover, the degradation of zinc-based alloys does not induce hydrogen [6]. The studies concerning degradable Mg-based alloys have proven that hydrogen released from $\mathrm{Mg}$ based alloys seriously hinders the growth and healing of nearby bone tissue. At the same 
time, the increasing $\mathrm{pH}$ value of the body fluid around the material caused by rapid corrosion would lead to serious inflammation. However, this case would be avoided for $\mathrm{Zn}$ and its alloys [11].

However, there are still some issues with zinc and its alloys. One of the drawbacks is that $\mathrm{Zn}$ and its alloys would induce more $\mathrm{Zn}$ ions, which are reported to be cytotoxic to cells [12]. Although zinc alloys showed good biocompatibility in in vivo assays, previous studies showed that cells exposed directly to zinc and its alloys would hardly survive [13]. $\mathrm{Ma}$ [5] found that the cellular response depended on the concentration of $\mathrm{Zn}$ ions. The low concentrations of $\mathrm{Zn}$ ions could enhance cell proliferation, whereas greater concentrations could have the opposite effect on cells. Elevated concentrations of zinc ions can affect the adhesion and migration of aortic smooth muscle cells and human fibroblasts. Shearer et al. [10] investigated the cytotoxicity, adhesion, and proliferation of aortic smooth muscle cells and human fibroblasts on pure zinc, and found that half of these cells were in apoptosis, but the gelatin-modified zinc surface could favor cell adhesion and proliferation. Yin et al. [14], who investigated the blood compatibility of $\mathrm{Zn}-0.8 \mathrm{wt} . \%(\mathrm{Cu}, \mathrm{Mn}, \mathrm{Li})$ alloys in vitro, reported that the blood platelet adhered on the three zinc alloys was circular and less distributed.

Surface coating is a technique used to effectively improve the surface corrosion resistance and biocompatibility of biomaterials. More and more researchers began to pay attention to the surface modification of zinc and its alloys. In recent years, the chemical deposition method, electrochemical method, micro-arc oxidation or anodic oxidation method, gel method, and atomic layer deposition polymer have been developed to improve the biocompatibility of zinc and its alloys [8,15-20]. Yuan [15] used atomic layer deposition to develop a $\mathrm{ZrO}_{2}$ nanofilm on the $\mathrm{Zn}-0.1 \mathrm{Li}$ alloy. The chemical deposition method is a feasible, efficient, and cost-effective way to fabricate a bioactive coating on zinc and its alloys. Besides, phosphate-based conversion coatings produced via the chemical deposition method have been widely studied to enhance the bioactivity and biocompatibility of zinc and its alloys. For example, Zhu used chemical deposition to fabricate an $\mathrm{Mg}$ phosphate coating on pure zinc to enhance cytocompatibility [21]. A zinc-phosphate (ZnP) coating with graphene oxide was developed on pure zinc by Zhang [19] to improve the degradation behavior. Mo [22] also produced an alendronate-decorated zinc phosphate coating on pure zinc. Since the composition structure of calcium phosphate coatings is similar to human bone, the calcium phosphate coatings show excellent biocompatibility and a bone induction effect, which can promote the adhesion, proliferation, and differentiation of osteoblasts [23]. Therefore, calcium phosphate coatings have been widely used in bone materials. For example, some studies showed that the preparation of a calcium and phosphate coating on the Mg-based alloys extends the bone tissue into the porous surface, and can stabilize and decrease the degradation rate of Mg-based alloys, making the Mg-based alloys corrode uniformly in saline and cellular solution [24]. Therefore, the calcium phosphate coating may play a key role in regulating the degradation rate and biological activity of zinc-based alloys. Meanwhile, to improve the biological activity of the calcium phosphate coating, some bioactive elements required by bone formation are introduced into the coatings, such as $\mathrm{Sr}^{2+}, \mathrm{F}^{-}, \mathrm{Mg}^{2+}$, and $\mathrm{SiO}_{4}{ }^{4-}$ [25]. Strontium, as one of the essential trace elements, would prevent arteriosclerosis and thrombosis in the human body [26]. Moreover, the Sr-modified calcium phosphate coatings promote cell proliferation and differentiation, while inhibiting resorption and osteoclast differentiation [27]. Therefore, the Sr-doped calcium phosphate conversion coating may address the cytotoxicity of pure zinc induced by the accumulated $\mathrm{Zn}$ ions.

To regulate degradation and cell compatibility of pure zinc, the Ca-P-Sr conversion coating was synthesized on the pure zinc by the hydrothermal method, and the microstructure, corrosion behavior, and cytocompatibility of the coating were investigated to confirm its feasibility for application in the clinic. 


\section{Experimental Detail}

\subsection{Materials' Preparation}

The zinc plates $(\mathrm{Zn} \geq 99.99 \%, \varphi 10 \mathrm{~mm} \times 2 \mathrm{~mm}$ ) were ground to 2000\# with sandpaper, then cleaned with deionized water in ultrasonic equipment. The coating was produced by the hydrothermal method, as shown in Figure 1. Briefly, the samples were exposed in autoclaves consisting of $0.15 \mathrm{M} \mathrm{CaCl}_{2}, 0.12 \mathrm{M} \mathrm{NaH}_{2} \mathrm{PO}_{4}, 0.05 \mathrm{M} \mathrm{Sr}_{3}\left(\mathrm{NO}_{3}\right)_{2}$, and $0.1 \mathrm{M}$ $\mathrm{Na}_{2}$ EDTA $2 \mathrm{H}_{2} \mathrm{O}$, with the $\mathrm{pH}$ of 4 at $130{ }^{\circ} \mathrm{C}$ for $5 \mathrm{~h}$. The synthesis conditions used in this study were based on our previous optimal work.

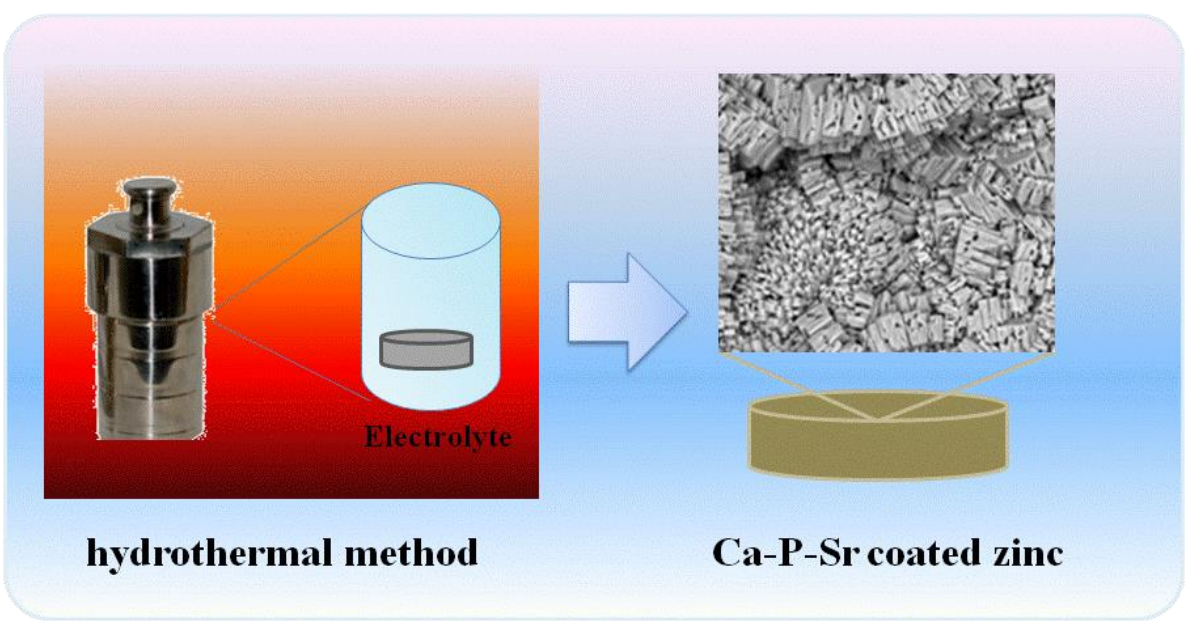

Figure 1. Diagram of producing the Ca-P-Sr coating using the hydrothermal method.

\subsection{Coating Characterization}

The microstructure of the Ca-P-Sr coatings was analyzed by a scanning electron microscope (HITACHI S-3400, Hitachi, Japan). The coating composition was characterized using an electron energy spectrometer (EDS, Oxford Instrument, Oxford, Britain). An X-ray diffraction (XRD, Bruker D8 Advance, Karlsruhe, Germany) instrument with $\mathrm{Cu} \mathrm{K} \alpha$ radiation was used to detect the coating phase. The data were obtained in the $2 \theta$ range of 10-90 with a step size of $5^{\circ}$ and a dwell time of 5 s per step. The contact angles of the coating were detected using a contact angle meter (KRÜSS, DSA-25E, Hamburg, Germany).

\subsection{Immersion Test}

The degradation behavior was evaluated via the immersion test in simulated body fluid (SBF) for 14 days at $37^{\circ} \mathrm{C}$. The $\mathrm{pH}$ value of the simulated body fluid immersed with samples was recorded every 2 days. Meanwhile, the concentration of Zn ions was also detected by an inductively coupled plasma atomic emission spectrometer (ICP-AES, Ultima 2, HORIBA Jobin Yvon, Paris, France) every 2 days. Three duplicates were used for the $\mathrm{pH}$ and ICP tests. The composition of the SBF solution referred to Reference [22].

\subsection{Electrochemical Corrosion}

The electrochemical corrosion was studied via the electrochemical measurement (Princeton Model 273A) in SBF solution at $37^{\circ} \mathrm{C}$. The three-electrode system was used in the electrochemical corrosion tests: zinc was used as the working electrode, the platinum sheet was used as the auxiliary electrode, and calomel was used as the parameter electrode. The working sample area exposed to electrolytes was about $1 \mathrm{~cm}^{2}$. The scanning range was -0.5 to $+1.5 \mathrm{~V}$, and the scanning speed was set as $1 \mathrm{mV} / \mathrm{s}$. Three duplicates were used for the electrochemical test. The corrosion rate, $\mathrm{R}$ (mpy), was calculated by Gamry Echem Analyst software, and was then multiplied by 0.0254 to convert into the corrosion rate, $\mathrm{R}(\mathrm{mm} / \mathrm{a})$. 


\subsection{Cell Viability and ALP Activity}

Cytotoxicity of the pure zinc and coated zinc was assessed following the experimental method of the CCK-8 kit according to the operating instructions: $100 \mu \mathrm{L}$ of MC3T3-E1 with a density of $5 \times 10^{4}$ cells $/ \mathrm{mL}$ was seeded into the 96-well plate placed with the studied sample, and cultured in an incubator with $5 \% \mathrm{CO}_{2}$ atmosphere at $37{ }^{\circ} \mathrm{C}$ for 1,3 , and 5 days. At each time point, $20 \mu \mathrm{L}$ of CCK-8 was added into 96-well plates placed with the studied samples and then incubated in a $5 \% \mathrm{CO}_{2}$ incubator for $2 \mathrm{~h}$, at $37^{\circ} \mathrm{C}$. Then, the optical density (OD) per well was detected at $450 \mathrm{~nm}$ using a microplate reader. As for the alkaline phosphatase (ALP) activity, $100 \mu \mathrm{L}$ of MC3T3-E1 with a density of $5 \times 10^{4}$ cells $/ \mathrm{mL}$ and $1 \mathrm{~mL}$ of medium containing the derivate were seeded into the 24-well plate placed with the studied sample, and cultured in an incubator with a $5 \% \mathrm{CO}_{2}$ atmosphere at $37^{\circ} \mathrm{C}$ for 7 and 14 days. The culture medium containing the derivate was refreshed every other day. At each time point, after aspirating the medium, the samples were washed three times with PBS. Then, $500 \mu \mathrm{L}$ of $0.2 \%$ Tritonx-100 lysate was added into each well, and cultured overnight. After that, $50 \mu \mathrm{L}$ of lysate was adopted and added to the 96-well plates, then $50 \mu \mathrm{L}$ of the chromogenic substrate was added into each well and incubated for $30 \mathrm{~min}$ at $37^{\circ} \mathrm{C}$. Next, $100 \mu \mathrm{L}$ of $\mathrm{NaOH}$ reaction was added per well to terminate the reaction, and was detected at $450 \mathrm{~nm}$ using a microplate reader to obtain the OD per well.

\subsection{Statistical Analysis}

Data were analyzed using the SPSS 13.0 software package, and mean values were compared using the $t$-test. The difference was considered significant when $p<0.05$.

\section{Results and Discussion}

\subsection{Analysis of $\mathrm{Ca}-\mathrm{P}$-Sr Coating}

Figure 2a displays the morphology of the conversion of the Ca-P-Sr-coated sample. Under low magnification, it can be seen that a strip-like coating covered the surface of the pure zinc. The higher magnification in Figure $2 \mathrm{~b}$ demonstrated that the coating morphology was composed of rock-like crystals, which were decorated with lots of holes. The rock-like crystals were stacked on top of each other. Actually, once pure zinc was soaked with the electrolyte, heterogeneous nucleation of crystals began to form on the substrate, which then gradually translated into an inner dense layer. As a process, the crystals are then deposited on the inner layer stack-by-stack. In this case, there are a lot of cracks and pores in the crystal layer [23]. The corresponding EDS results in Figure 2c suggested that the main elements of the coating were $\mathrm{Ca}, \mathrm{P}, \mathrm{Sr}$, and $\mathrm{O}$. The cross-section image of the coated zinc is shown in Figure 2d. The compact and dense coating was well-combined to the matrix with no observable defects, such as cracks and pores. Moreover, the thickness of the Ca-P-Sr was approximately $48 \pm 4 \mu \mathrm{m}$.

The XRD patterns of pure zinc and the Ca-P-Sr-coated zinc are presented in Figure 3a. The strongest intensity of the peaks from both samples was assigned to the zinc, while the peaks at $38.2^{\circ}, 46.0^{\circ}$, and $55.1^{\circ}$ from coating belonged to $\mathrm{CaHPO}_{4}$, indicating that the main phase of the coating was $\mathrm{CaHPO}_{4}$. Moreover, local XRD patterns ranged from 10 to 30 degrees of coated zinc, obtained from Figure $3 a$, suggesting that $\mathrm{CaSr}_{2}\left(\mathrm{PO}_{4}\right) \cdot 2 \mathrm{H}_{2} \mathrm{O}$ was detected in the coating (Figure $3 b$ ). The surface wettability of the pure zinc and coated zinc is displayed in Figure 3c. As a rule, surface wettability is greatly associated with the bioactivity of biomaterials, and surface hydrophilicity can favor the attachment and proliferation of cells. The result of the surface wettability suggested that the coating significantly reduced the contact angles of pure zinc, indicating that the surface hydrophilicity was improved after the fabrication of the Ca-P-Sr coating. 

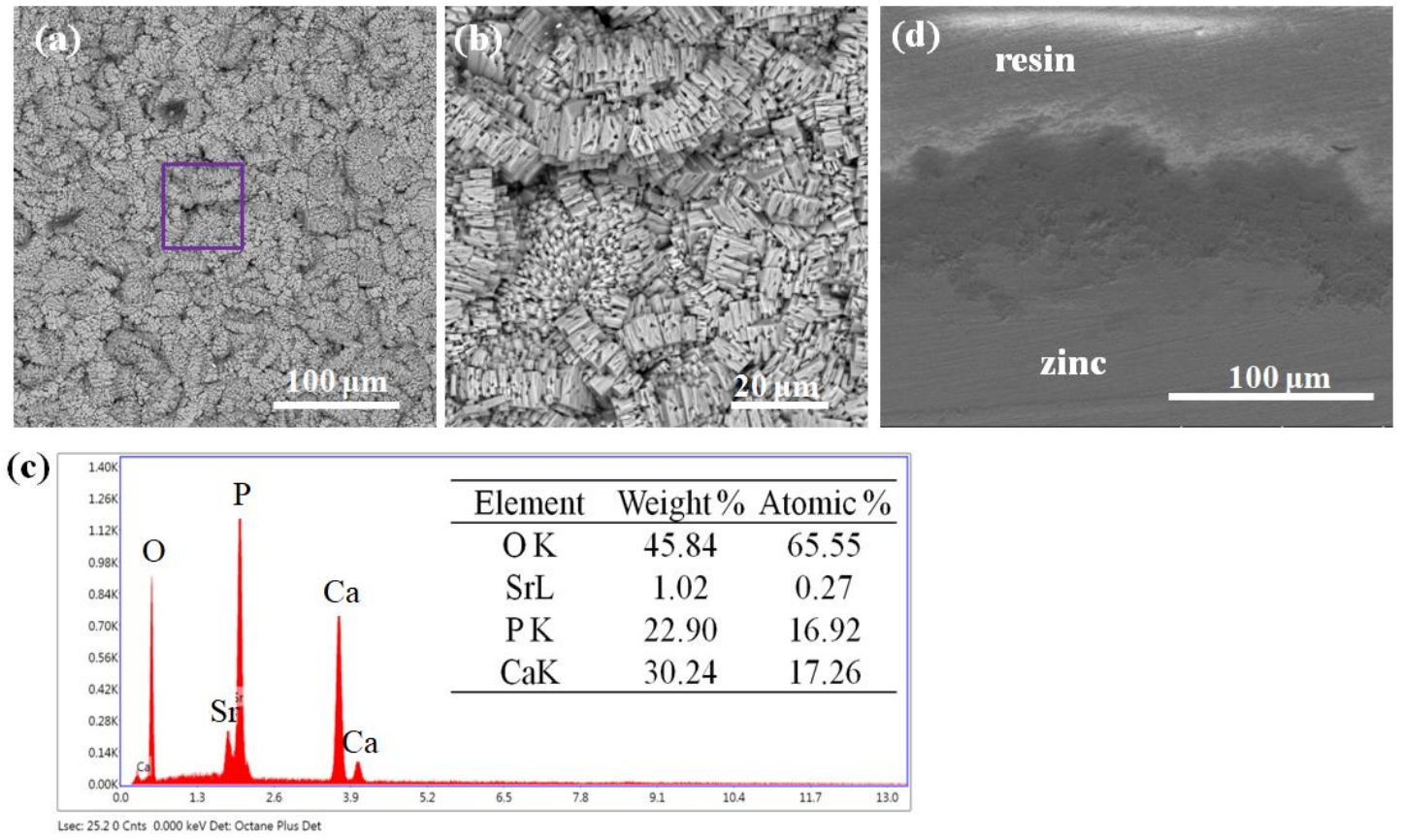

Figure 2. (a) The microstructure of the coated sample, (b) higher magnification of Figure 1a, (c) corresponding EDS results from Figure 1a, and (d) the cross-section image of the coated zinc.
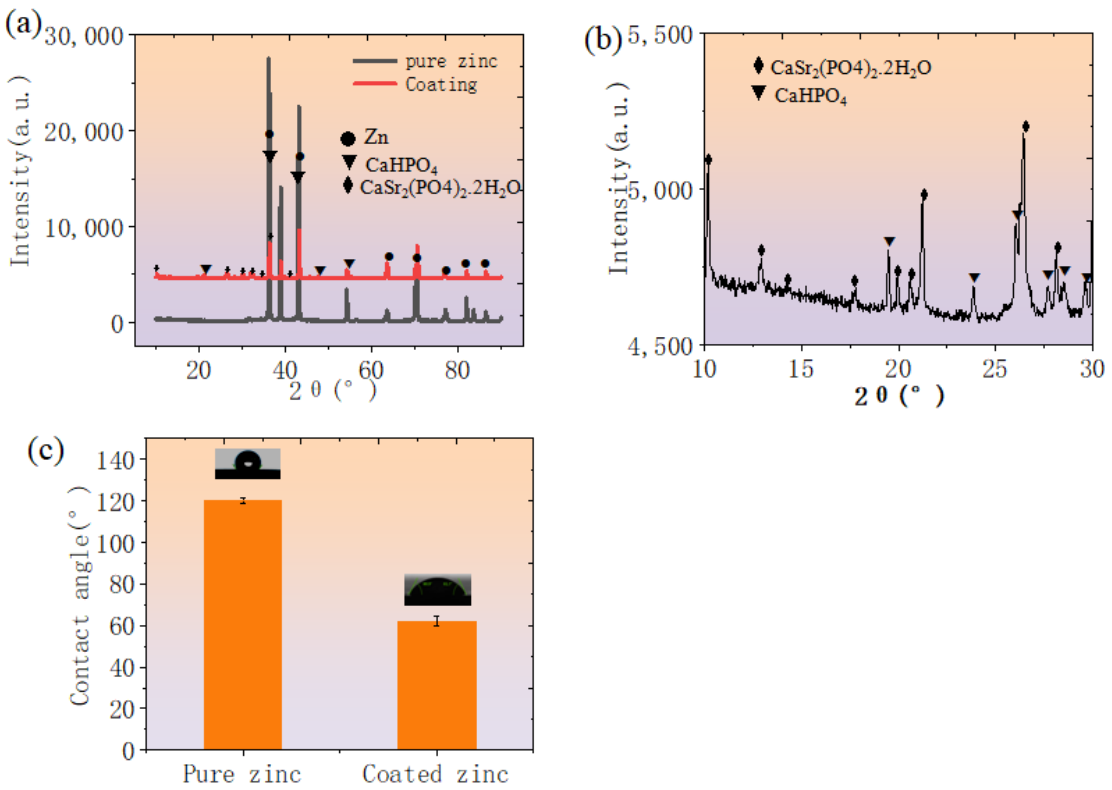

Figure 3. (a) XRD patterns of pure zinc and Ca-P-Sr-coated zinc, (b) the local XRD pattern ranged from 10 to 30 degrees of coated zinc, obtained from Figure $3 a$, and (c) surface wettability of the pure zinc and coated zinc.

\subsection{Corrosion Behavior}

The corrosion resistance of the coated zinc was evaluated using the potentiodynamic polarization at $37^{\circ} \mathrm{C}$ in SBF solution, as presented in Figure 4, and the corresponding parameters are listed in Table 1 . Generally, in the polarization curve, the cathodic branch is dominated by hydrogen evolution, and metal dissolution is related to the anodic branch. As can be seen from Figure 4, the current densities of the cathodic and anodic branches in the coated sample were reduced concerning pure zinc, suggesting that the corrosion resistance of pure zinc was elevated. Moreover, the corrosion potential of the coated zinc 
shifted to a more positive potential than the pure zinc, which indicated that the corrosion thermodynamic tendency was reduced by the presence of the coating. As shown in Table 1, the corrosion potential increased from -1.12 to $-1.01 \mathrm{mV}$, while the corrosion current density was reduced from $8.57 \times 10^{-5}$ to $6.21 \times 10^{-5} \mathrm{~A} . \mathrm{cm}^{-2}$. The in vitro corrosion rate of coated pure zinc was about $0.015 \mathrm{~mm}$ /year, which was lower than that of pure zinc $(0.07 \mathrm{~mm} /$ year $)$, indicating that the corrosion rate was improved by the coating.

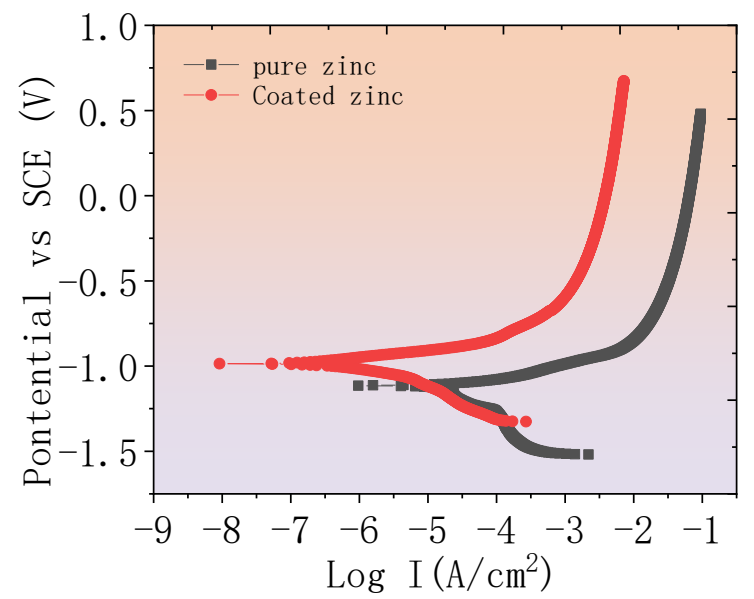

Figure 4. The potentiodynamic polarization curves of the studied zinc.

Table 1. The corrosion current density and corrosion potential.

\begin{tabular}{cccc}
\hline Sample & Icorr $\mathbf{( A / \mathbf { c m } ^ { 2 }}$ ) & Ecorr $\mathbf{( V )}$ & Corrosion Rate (mpy) \\
\hline Pure zinc & $8.57 \times 10^{-5} \pm 3.14 \times 10^{-6}$ & $-1.12 \pm 0.04$ & $2.78 \pm 0.81$ \\
Coated zinc & $6.21 \times 10^{-6} \pm 2.89 \times 10^{-7}$ & $-1.01 \pm 0.06$ & $0.59 \pm 0.14$ \\
\hline
\end{tabular}

\subsection{Degradation Behavior}

When the zinc and its alloys are exposed to the electrolyte, the following electrochemical reactions would occur [28]:

$$
\begin{gathered}
\text { Anodic reaction: } \mathrm{Zn} \rightarrow \mathrm{Zn}^{2+}+2 \mathrm{e}^{-} \\
\text {Cathodic reaction: } \mathrm{H}_{2} \mathrm{O}+1 / 2 \mathrm{O}_{2} \rightarrow 2 \mathrm{OH}^{-}
\end{gathered}
$$

To further determine the degradation behavior of the coated zinc, the immersion tests in terms of $\mathrm{pH}$ and $\mathrm{Zn}$ ion release were conducted in $\mathrm{SBF}$ solution at $37^{\circ} \mathrm{C}$, as shown in Figure 5. The $\mathrm{pH}$ curves of the pure zinc and coated zinc after samples were immersed in SBF for 15 days are displayed in Figure 5a. The $\mathrm{pH}$ value of the pure zinc rapidly increased on the first day, and reached the highest value on the third day. Then, the $\mathrm{pH}$ value gradually reduced with time. This is due to the deposition of the corrosion product on the zinc substrate. However, the $\mathrm{pH}$ curves showed a fluctuating profile, which was caused by an alternative in pit corrosion, generation, and degradation of corrosion products. On the contrary, the Ca-P-Sr coating greatly reduced the $\mathrm{pH}$ value during the immersion time, and the $\mathrm{pH}$ value remained relatively stable. The $\mathrm{pH}$ values for pure zinc and Ca-PSr-coated zinc were about 8.14 and 7.92 after a 15-day immersion. It has to be noted that the $\mathrm{pH}$ values dropped slightly at 7 and 13 days. The explanation may be that there was an alternative in degradation of the coating and generation of corrosion products on coatings. When the coating was exposed to the solution, the degradation of the coating occurred, and then the solution infiltrated into the substrate. Meanwhile, the corrosion products were also deposited on the coatings, which may contribute to protecting the substrate. Figure $5 \mathrm{~b}$ shows the amount of $\mathrm{Zn}$ ions dissolved from pure zinc and Ca-P-Sr-coated zinc. Similar to the $\mathrm{pH}$ value, the concentration of $\mathrm{Zn}$ ions released from the coated zinc was significantly 
suppressed, suggesting that the Ca-P-Sr coating could improve corrosion resistance. The above results indicated that the coating on pure zinc could limit the release of $\mathrm{OH}-$ and zinc ions.
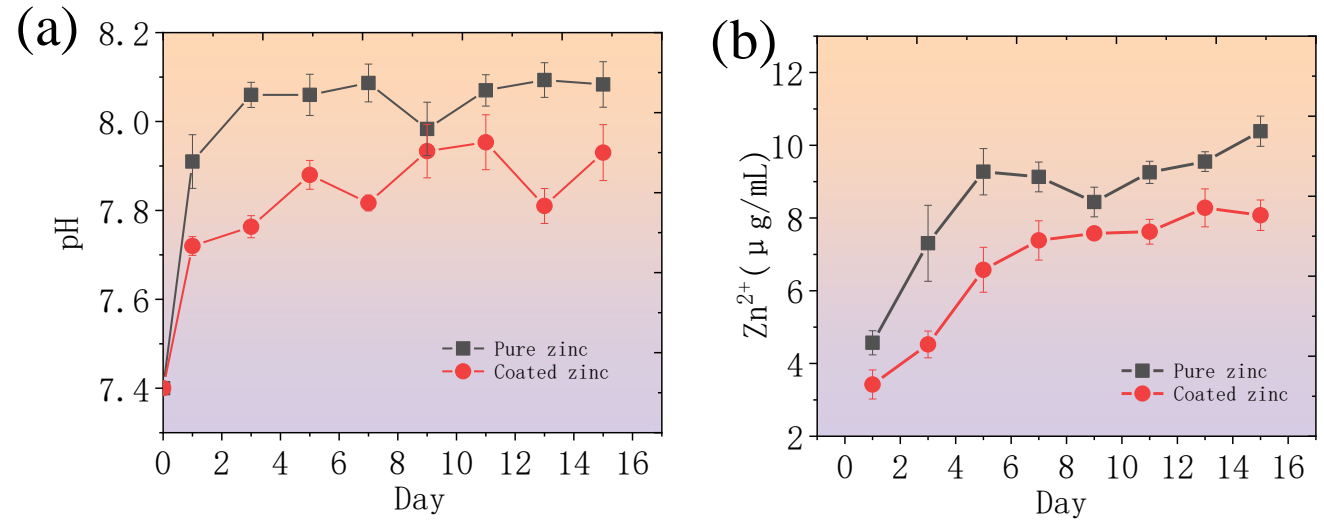

Figure 5. (a) The $\mathrm{pH}$ of SBF solution after holding zinc samples with and without coating for 15 days, and (b) the amount of $\mathrm{Zn}^{2+}$ ions in SBF solution after holding zinc samples with and without coating for 15 days.

\subsection{Cell Activity and ALP Activity}

Figure 6a presents the cell activity of pure zinc and coated zinc exposed to MC3T3-E1 for 1,3, and 5 days. It can be seen that there was almost no cell activity in the pure zinc group. This indicated that the cell proliferation may be inhibited by the accumulated zinc ions and $\mathrm{pH}$ value. However, this issue was improved by the coating, whereby the cell activity of coated zinc gradually increased with time, suggesting that the cytocompatibility of pure zinc was significantly improved. Moreover, the cell activity was also evaluated by ALP. The ALP expression levels of the cells in the samples studied for 14 days were shown in Figure 6b. As it is known, ALP, a specific marker of osteoblast differentiation, is one of the most common indicators of evaluating the secretion function of osteoblasts, which is closely related to the ability of osteoblast differentiation. The continued expression of ALP is an important marker for detecting bone mineralization and osteogenesis via favoring hydrolysis of multiple phosphates under alkaline conditions. Similar to the results of cell activity, the ALP expression on the pure zinc was inhibited during the culture time, mainly resulting from the cytotoxicity induced by the high zinc ion concentration. In this study, the expression of ALP in the coated samples was significantly improved concerning the bare zinc, showing that the ALP activity of cells grown on the coating had a significant enhancement.

(a)

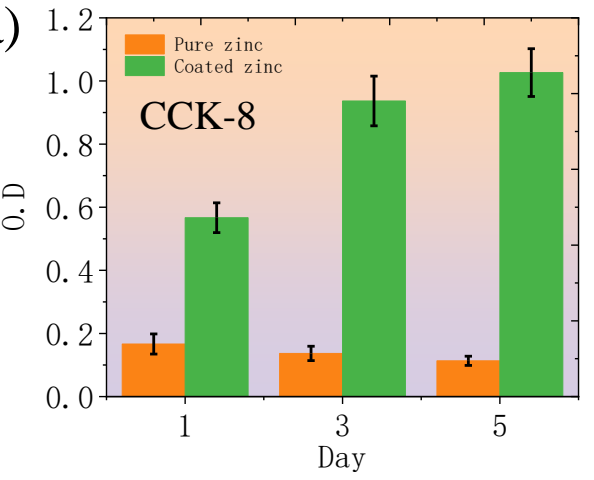

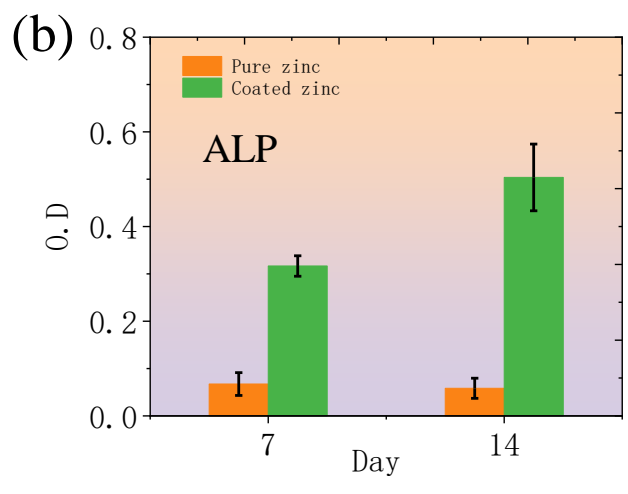

Figure 6. (a) The cell activity of pure zinc and coated zinc exposed to MC3T3-E1, and (b) ALP expression level of the studied samples for 7 and 14 days.

It has been proven that the microenvironment induced by biomaterials is greatly affected by the cell proliferation and differentiation on the implant [29]. Given this, bio- 
material with good biocompatibility is required. To overcome this issue, some researchers have fabricated phosphate-based coatings on zinc and its alloys. For example, Zhang [19] controlled the degradation behavior and cytocompatibility of pure zinc by fabricating a graphene oxide-modified zinc-phosphate coating. Mo [22] fabricated an alendronatedecorated zinc phosphate coating for pure zinc to reduce the degradation rate, and the bioactivity reported that the alendronate-decorated zinc phosphate coating could significantly decrease the corrosion rate and promote a pro-osteoblast response. Additionally, Zhuang found that the Ca-P coating could modulate the osteogenic differentiation of BMSCs [30]. The above studies indicated that reducing the $\mathrm{pH}$ value and the concentration of zinc ions accumulated around the implant were the main reasons for improvement of the cytocompatibility. On one hand, the alkaline microenvironment is greatly relevant to the cell adhesion on the implant [31]. Reducing the $\mathrm{pH}$ value due to the presence of a coating on pure zinc could promote cell differentiation [32]. On the other hand, although zinc ions are required for bone formation, there is increasing evidence showing that an excessive release of zinc ions from implants would induce cytotoxicity [33]. A previous study pointed out that the zinc ions of more than $80 \mu \mathrm{M}$ would induce a negative biocompatibility [5]. Thanks to the Ca-P-Sr coating, the negative biocompatibility was addressed by fabricating the coating on pure zinc. The coating led to the decreased corrosion rate, which was close to the benchmark value, for a degradation rate of $0.02 \mathrm{~mm}$ /year. In this study, the in vitro corrosion rate of $0.015 \mathrm{~mm}$ /year may lead to more compatibility. However, the ideal in vitro corrosion rate should be supported by more data, since it is affected by many factors, including the $\mathrm{pH}$ value of the physiological environment, the composition of materials and devices, and so on. Besides, it has to be mentioned that $\mathrm{Ca}$ and $\mathrm{Sr}$ may be other factors that promote cell proliferation, since $\mathrm{Ca}$ and $\mathrm{Sr}$ are important components during bone formation. Extensive studies have demonstrated that the introduction of $\mathrm{Ca}$ and $\mathrm{Sr}$ in the coatings greatly favors excellent cell proliferation and ALP activity of osteoblasts [34,35]. In this study, the presence of $\mathrm{Ca}$ and $\mathrm{Sr}$ possibly helped to promote cell proliferation and ALP activity. However, further investigation should be conducted to confirm this positive effect of the Ca-P-Sr coating on osteoblast response in vitro and in vivo.

\section{Conclusions}

In this study, a dense Ca-P-Sr bioactive coating was successfully prepared on the surface of pure zinc by the hydrothermal method to improve the cytocompatibility. The CaP-Sr coating is composed of rock-like crystals with pores, which were stacked one by one. The main phase of the Ca-P-Sr coating was $\mathrm{CaHPO}_{4}$ and $\mathrm{CaSr}_{2}\left(\mathrm{PO}_{4}\right) \cdot 2 \mathrm{H}_{2} \mathrm{O}$. The corrosion rate of pure zinc was regulated by fabricating the Ca-P-Sr coating, showing a lower amount of zinc ion release and a lower $\mathrm{pH}$ value. More importantly, the presence of the Ca-P-Sr coating greatly favored cell proliferation, showing good cytocompatibility. Therefore, the Ca-P-Sr coating was shown as a promising application to address the cytocompatibility of zinc and its alloys.

Author Contributions: Conceptualization, M.K.; methodology, M.K.; formal analysis, M.K.; investigation, S.S.; data curation, M.K. and Q.T.; writing-original draft preparation, M.K. and S.S.; writing-review and editing, S.S. and D.X. All authors have read and agreed to the published version of the manuscript.

Funding: This research was funded by Project of Natural Science Foundation of Fujian Province (Grant No. 2021J011156).

Institutional Review Board Statement: Not applicable.

Informed Consent Statement: Not applicable.

Data Availability Statement: No new data were created or analyzed in this study. Data sharing is not applicable to this article.

Conflicts of Interest: The authors declare no conflict of interest. 


\section{References}

1. Katarivas Levy, G.; Goldman, J.; Aghion, E. The Prospects of Zinc as a Structural Material for Biodegradable Implants-A Review Paper. Metals 2017, 7, 402. [CrossRef]

2. Kabir, H.; Munir, K.; Wen, C.; Li, Y. Recent research and progress of biodegradable zinc alloys and composites for biomedical applications: Biomechanical and biocorrosion perspectives. Bioact. Mater. 2021, 6, 836-879. [CrossRef] [PubMed]

3. Guan, R.-G.; Cipriano, A.F.; Zhao, Z.-Y.; Lock, J.; Tie, D.; Zhao, T.; Cui, T.; Liu, H. Development and evaluation of a magnesiumzinc-strontium alloy for biomedical applications-Alloy processing, microstructure, mechanical properties, and biodegradation. Mater. Sci. Eng. C 2013, 33, 3661-3669. [CrossRef] [PubMed]

4. Kafri, A.; Ovadia, S.; Yosafovich-Doitch, G.; Aghion, E. The Effects of 4\%Fe on the Performance of Pure Zinc as Biodegradable Implant Material. Ann. Biomed. Eng. 2019, 47, 1400-1408. [CrossRef]

5. Ma, J.; Zhao, N.; Zhu, D. Endothelial Cellular Responses to Biodegradable Metal Zinc. ACS Biomater. Sci. Eng. 2015, 1, 1174-1182. [CrossRef]

6. Mostaed, E.; Sikora-Jasinska, M.; Drelich, J.W.; Vedani, M. Zinc-based alloys for degradable vascular stent applications. Acta Biomater. 2018, 71, 1-23. [CrossRef]

7. Yang, H.; Jia, B.; Zhang, Z.; Qu, X.; Li, G.; Lin, W.; Zhu, D.; Dai, K.; Zheng, Y. Alloying design of biodegradable zinc as promising bone implants for load-bearing applications. Nat. Commun. 2020, 11, 401. [CrossRef] [PubMed]

8. Peng, F.; Lin, Y.; Zhang, D.; Ruan, Q.; Tang, K.; Li, M.; Liu, X.; Chu, P.K.; Zhang, Y. Corrosion Behavior and Biocompatibility of Diamond-like Carbon-Coated Zinc: An In Vitro Study. ACS Omega 2021, 6, 9843-9851. [CrossRef]

9. Seitz, J.-M.; Durisin, M.; Goldman, J.; Drelich, J.W. Recent Advances in Biodegradable Metals for Medical Sutures: A Critical Review. Adv. Healthc. Mater. 2015, 4, 1915-1936. [CrossRef]

10. Shearier, E.R.; Bowen, P.K.; He, W.; Drelich, A.; Drelich, J.; Goldman, J.; Zhao, F. In Vitro Cytotoxicity, Adhesion, and Proliferation of Human Vascular Cells Exposed to Zinc. ACS Biomater. Sci. Eng. 2016, 2, 634-642. [CrossRef]

11. Li, P.; Qian, J.; Zhang, W.; Schille, C.; Schweizer, E.; Heiss, A.; Klotz, U.E.; Scheideler, L.; Wan, G.; Geis-Gerstorfer, J. Improved biodegradability of zinc and its alloys by sandblasting treatment. Surf. Coat. Technol. 2021, 405, 126678. [CrossRef]

12. Guillory, R.J., 2nd; Kolesar, T.M.; Oliver, A.A.; Stuart, J.A.; Bocks, M.L.; Drelich, J.W.; Goldman, J. Zn(2+)-dependent suppression of vascular smooth muscle intimal hyperplasia from biodegradable zinc implants. Mater. Sci. Eng. C Mater. Biol. Appl. 2020, 111, 110826. [CrossRef] [PubMed]

13. Su, Y.; Cockerill, I.; Wang, Y.; Qin, Y.-X.; Chang, L.; Zheng, Y.; Zhu, D. Zinc-Based Biomaterials for Regeneration and Therapy. Trends Biotechnol. 2019, 37, 428-441. [CrossRef] [PubMed]

14. Yin, Y.-X.; Zhou, C.; Shi, Y.-P.; Shi, Z.-Z.; Lu, T.-H.; Hao, Y.; Liu, C.-H.; Wang, X.; Zhang, H.-J.; Wang, L.-N. Hemocompatibility of biodegradable Zn-0.8 wt\% (Cu, Mn, Li) alloys. Mater. Sci. Eng. C 2019, 104, 109896. [CrossRef]

15. Yuan, W.; Xia, D.; Zheng, Y.; Liu, X.; Wu, S.; Li, B.; Han, Y.; Jia, Z.; Zhu, D.; Ruan, L.; et al. Controllable biodegradation and enhanced osseointegration of $\mathrm{ZrO}_{2}$-nanofilm coated $\mathrm{Zn}$-Li alloy: In vitro and in vivo studies. Acta Biomater. 2020, 105, $290-303$. [CrossRef] [PubMed]

16. Shomali, A.A.; Guillory, R.J.; Seguin, D.; Goldman, J.; Drelich, J.W. Effect of PLLA coating on corrosion and biocompatibility of zinc in vascular environment. Surf. Innov. 2017, 5, 211-220. [CrossRef]

17. Mousa, H.M.; Abdal-Hay, A.; Bartnikowski, M.; Mohamed, I.M.A.; Yasin, A.S.; Ivanovski, S.; Park, C.H.; Kim, C.S. A Multifunctional Zinc Oxide/Poly(Lactic Acid) Nanocomposite Layer Coated on Magnesium Alloys for Controlled Degradation and Antibacterial Function. ACS Biomater. Sci. Eng. 2018, 4, 2169-2180. [CrossRef]

18. Pezzato, L.; Settimi, A.G.; Cerchier, P.; Gennari, C.; Dabalà, M.; Brunelli, K. Microstructural and Corrosion Properties of PEO Coated Zinc-Aluminized (ZA) Steel. Coatings 2020, 10, 448. [CrossRef]

19. Zhang, L.; Tong, X.; Lin, J.; Li, Y.; Wen, C. Enhanced corrosion resistance via phosphate conversion coating on pure Zn for medical applications. Corros. Sci. 2020, 169, 108602. [CrossRef]

20. Serdechnova, M.; Blawert, C.; Karpushenkov, S.; Karpushenkava, L.; Shulha, T.; Karlova, P.; Vasilić, R.; Stojadinović, S.; Damjanović-Vasilić, L.; Heitmann, V.; et al. Properties of ZnO/ZnAl2O4 composite PEO coatings on zinc alloy Z1. Surf. Coat. Technol. 2021, 410, 126948. [CrossRef]

21. Zhu, M.; Lu, Y.; Zhang, C.; Li, L.; Xie, M.; Lin, J.; Tang, K. Facile fabrication of Mg-based coating to improve the biodegradable behavior and cytocompatibility of pure zinc. Surf. Coat. Technol. 2019, 372, 209-217. [CrossRef]

22. Mo, X.; Qian, J.; Chen, Y.; Zhang, W.; Xian, P.; Tang, S.; Zhou, C.; Huang, N.; Ji, H.; Luo, E.; et al. Corrosion and degradation decelerating alendronate embedded zinc phosphate hybrid coating on biodegradable Zn biomaterials. Corros. Sci. 2021, 184, 109398. [CrossRef]

23. Hafeez, M.A.; Farooq, A.; Zang, A.; Saleem, A.; Deen, K.M. Phosphate chemical conversion coatings for magnesium alloys: A review. J. Coat. Technol. Res. 2020, 17, 827-849. [CrossRef]

24. Correa, P.; Malfatti, C.; Azambuja, D. Corrosion behavior study of AZ91 magnesium alloy coated with methyltriethoxysilane doped with cerium ions. Prog. Org. Coat. 2011, 72, 739-747. [CrossRef]

25. Ma, J.; Wang, C.Z.; Huang, B.X.; Zhao, X.C.; Chen, C.Z.; Yu, H.J. In vitro degradation and apatite formation of magnesium and zinc incorporated calcium silicate prepared by sol-gel method. Mater. Technol. 2021, 36, 420-429. [CrossRef] 
26. Zhao, D.-W.; Liu, C.; Zuo, K.-Q.; Su, P.; Li, L.-B.; Xiao, G.-Y.; Cheng, L. Strontium-zinc phosphate chemical conversion coating improves the osseointegration of titanium implants by regulating macrophage polarization. Chem. Eng. J. 2021, 408, 127362. [CrossRef]

27. Boyd, A.; Rutledge, L.; Randolph, L.; Meenan, B. Strontium-substituted hydroxyapatite coatings deposited via a co-deposition sputter technique. Mater. Sci. Eng. C 2015, 46, 290-300. [CrossRef]

28. Bao, G.; Fan, Q.; Ge, D.; Wang, K.; Sun, M.; Zhang, Z.; Guo, H.; Yang, H.; He, B.; Zheng, Y. In vitro and in vivo studies to evaluate the feasibility of $\mathrm{Zn}-0.1 \mathrm{Li}$ and $\mathrm{Zn}-0.8 \mathrm{Mg}$ application in the uterine cavity microenvironment compared to pure zinc. Acta Biomater. 2021, 123, 393-406. [CrossRef]

29. Hu, Y.; Cai, K.; Luo, Z.; Zhang, Y.; Li, L.; Lai, M.; Hou, Y.; Huang, Y.; Li, J.; Ding, X.; et al. Regulation of the differentiation of mesenchymal stem cells in vitro and osteogenesis in vivo by microenvironmental modification of titanium alloy surfaces. Biomaterials 2012, 33, 3515-3528. [CrossRef]

30. Zhuang, Y.; Liu, Q.; Jia, G.; Li, H.; Yuan, G.; Yu, H. A Biomimetic Zinc Alloy Scaffold Coated with Brushite for Enhanced Cranial Bone Regeneration. ACS Biomater. Sci. Eng. 2021, 7, 893-903. [CrossRef]

31. Lin, J.Z.; Chen, W.D.; Tang, Q.Q.; Cao, L.Y.; Su, S.H. Lithium-modified MAO coating enhances corrosion resistance and osteogenic differentiation for pure magnesium. Surf. Interfaces 2021, 22, 100805. [CrossRef]

32. Wong, H.M.; Yeung, K.W.K.; Lam, K.O.; Tam, V.; Chu, P.K.; Luk, K.D.K.; Cheung, K.M.C. A biodegradable polymer-based coating to control the performance of magnesium alloy orthopaedic implants. Biomaterials 2010, 31, 2084-2096. [CrossRef] [PubMed]

33. Yuan, W.; Li, B.; Chen, D.; Zhu, D.; Han, Y.; Zheng, Y. Formation Mechanism, Corrosion Behavior, and Cytocompatibility of Microarc Oxidation Coating on Absorbable High-Purity Zinc. ACS Biomater. Sci. Eng. 2019, 5, 487-497. [CrossRef] [PubMed]

34. Amaravathy, P.; Kumar, T.S. Bioactivity enhancement by Sr doped Zn-Ca-P coatings on biomedical magnesium alloy. J. Magnes. Alloy. 2019, 7, 584-596. [CrossRef]

35. Costa, A.; Gemini-Piperni, S.; Alves, A.; Costa, N.; Checca, N.; Leite, P.; Rocha, L.; Pinto, A.; Toptan, F.; Rossi, A.; et al. TiO2 bioactive implant surfaces doped with specific amount of Sr modulate mineralization. Mater. Sci. Eng. C 2020, $120,111735$. [CrossRef] [PubMed] 